Fall 2007

\title{
The Emergence of Organized Feminist Resistance to Sexual Harassment in the United States in the 1970s
}

Carrie N. Baker

Smith College, cbaker@smith.edu

Follow this and additional works at: https://scholarworks.smith.edu/swg_facpubs

Part of the Women's Studies Commons

\section{Recommended Citation}

Baker, Carrie N., "The Emergence of Organized Feminist Resistance to Sexual Harassment in the United States in the 1970s" (2007). Study of Women and Gender: Faculty Publications, Smith College, Northampton, MA.

https://scholarworks.smith.edu/swg_facpubs/12 
The EMERGEnce of Organized Feminist Resistance to SeXUal HaRAsSMENT in the United

STATES IN THE 1970S

\section{Carrie N. Baker}

The first organized resistance to sexual harassment grew out of the women's movement, emerging at the intersection of activism against employment discrimination and feminist opposition to violence against women. The issue of sexual harassment brought together women's workplace concerns with resistance to male sexual aggression. In the mid-1970s two organizations formed to focus primarily on sexual harassment-Working Women United in Ithaca, New York, and the Alliance Against Sexual Coercion in Cambridge, Massachusetts. Based on archival materials and interviews, this article documents the early movement against sexual harassment, focusing particularly on the feminist activists who founded these organizations $<m>$ who they were and how they shaped the movement against sexual harassment. These women made significant contributions to the public understanding of sexual harassment and the development of legal prohibitions against it.

I hope this becomes a large movement-like rape, like battered women-a because it's also an issue of violence against women.

Freada Klein, Founder of the Alliance Against Sexual Coercion ${ }^{1}$

On a Sunday afternoon, the $4^{\text {th }}$ of May 1975, in the pouring rain, 275 women showed up at the Greater Ithaca Activities Center for the country's first speakout against sexual harassment. ${ }^{2}$ 
Sponsored by the newly formed Working Women United (WWU), as well as Cornell University's Human Affairs Program and the Ithaca chapter of the National Organization for Women, the speakout was described by organizer Karen Sauvigné as "awesome and powerful and well beyond our wildest expectations. ${ }^{3}$ About twenty women testified passionately about the devastating impact of sexual harassment on their lives. The women who spoke were diverse, young and old, black and white, and from a variety of occupations. They included an administrative assistant who worked at Cornell, three waitresses, a mailroom clerk, a factory shop steward, a secretary, an assistant professor, and an apprentice filmmaker. The women testified about "crude propositions to barter sex for employment, physical overtures and masturbatory displays, verbal abuse and hostile threats that appeared patently designed to intimidate woman and drive her out of her job. ${ }^{4}{ }^{4}$ They spoke about their feelings of self-blame, shame, and fear and described sexual harassment as "dehumanizing." They called sexual harassment an abuse of power and a structural condition of the workplace that they were no longer willing to tolerate. They expressed their appreciation for being able to talk about their experiences, one describing her testimony as a "catharsis." ${ }^{5}$ If one moment could pinpoint the birth of the movement against sexual harassment, this rainy Sunday afternoon in Ithaca, New York, would be it.

The first activism against sexual harassment emerged in the early 1970s in the form of lawsuits opposing sexual coercion in the workplace. Several women around the country who had been fired from their jobs for refusing the sexual advances of their bosses brought lawsuits alleging this treatment was a form of sex discrimination in violation of Title VII of the Civil Rights Act of 1964, which prohibits sex and race discrimination in employment. ${ }^{6}$ Several of these individuals were African American women who were familiar with Title VII precedent in 
the area of race discrimination. Racial harassment cases had succeeded under Title VII, so they used the same law, arguing that sexual coercion in the workplace was sex discrimination in violation of Title VII. ${ }^{7}$ Women lost most of these early cases, but appealed them and won several precedent-setting cases by the end of the 1970 s. $^{8}$

This article focuses on how collective resistance to sexual harassment emerged in the mid-1970s and contributed toward the appellate courts' decisions to reverse the lower courts and rule in favor of sexual harassment plaintiffs. Organized resistance to sexual harassment began with the founding of two grassroots organizations $<\mathrm{m}>$ Working Women United in Ithaca, New York, and the Alliance Against Sexual Coercion in Cambridge, Massachusetts. This article looks at the feminist activists who founded these organizations $<\mathrm{m}>$ who they were and how they shaped the movement against sexual harassment, particularly how their activism contributed toward the precedent-setting appellate court decisions that sexual harassment was sex discrimination in violation of Title VII.

Feminist activism grew out of the larger context of second wave activism against sex discrimination in the workplace under Title VII. After it became clear that the agency responsible for enforcing the Civil Rights Act, the Equal Employment Opportunity Commission, was not going to take women's workplace complaints under Title VII seriously, the National Organization for Women (NOW) formed in 1966 to push for enforcement of the Act. ${ }^{9}$ In the early 1970s, NOW targeted National Airlines because it had initiated a $\$ 9.5$ million advertising campaign that required female cabin crew to wear buttons saying "Fly Me." NOW denounced the advertising campaign and worked with National employees to file suit against National Airlines to stop the sexualization of women in the workplace. ${ }^{10}$ When activists in Ithaca began to articulate the wrong of sexual harassment, they turned to the National Organization for Women 
for guidance and support and drew upon their broad experience in the women's movement to organize against sexual exploitation in the workplace.

Resistance to sexual harassment emerged out of the women's movement at the intersection of activism against employment discrimination and feminist opposition to violence against women. The issue of sexual harassment brought together women's workplace concerns with feminist resistance to male sexual aggression. In the mid-1970s WWU formed in response to the case of a woman who was denied unemployment compensation when she quit a job because of sexual harassment. In anticipation of the May 1975 speakout, members of WWU coined the term "sexual harassment" to publicize the event, and they conducted the first survey of women's experiences of sexual harassment. The Alliance Against Sexual Coercion (AASC) was founded in 1976 by a group of women who had worked at a rape crisis center in Washington DC and had become concerned about the number of women they encountered who were facing sexual coercion on the job. AASC developed an in-depth feminist analysis of sexual harassment based on theory borrowed from the rape crisis movement and from Marxist theory of capitalist exploitation of labor. These roots shaped the perspectives and strategies of these two groups. Through counseling women and public education, these organizations raised awareness of the problem of sexual harassment and made a significant contribution to putting the issue of sexual harassment on the public agenda. The issue quickly caught on in the women's movement, and organizations across the country began organizing against sexual harassment, including organizations like Women Employed in Chicago, Federally Employed Women in Washington DC, and the Coalition of Labor Union Women in New York City. ${ }^{11}$

Many have credited lawyer and legal scholar Catharine MacKinnon as the pioneer of sexual harassment activism in the United States. She has been described as the "prime architect 
of sexual harassment jurisprudence" and has been given credit for proposing and popularizing the idea that sexual harassment constitutes sex discrimination and thus violates Title VII. ${ }^{12}$ As one scholar put it, rarely "has an author been as closely identified with a new cause of action as Catharine MacKinnon has been with sexual harassment."13 MacKinnon’s 1979 book Sexual Harassment of Working Women and her participation in the first Supreme Court case on sexual harassment, in particular, were foundational contributions to the development of sexual harassment law. ${ }^{14}$ A closer look at the history of the emergence of sexual harassment activism, however, reveals a broad and varied group of people were involved in conceptualizing and theorizing sexual harassment and creating legal prohibitions against it. Despite the fact that we rarely hear about these grassroots activists, they deserve recognition because of their significant contribution to the public understanding of sexual harassment and the development of legal prohibitions against it. The activism of grassroots groups was at the heart of the women's movement. As scholars increasingly reveal, grassroots efforts drove the second wave women's movement and were how feminists made the most significant social change. ${ }^{15}$

\section{Working Women United}

The formation of Working Women United in the spring of 1975 was inspired by the case of Carmita Wood, a forty-four-year-old mother of four who was denied unemployment compensation after she resigned as an administrative assistant to a Cornell professor because she had become physically ill from the stress of fending off his sexual advances. Wood sought support from the women's section of the Human Affairs Program (HAP) at Cornell University. Established in response to student uprisings in the late 1960s, HAP offered public-interestoriented courses on topics such as prison reform, urban redevelopment, and money and banking, 
incorporating fieldwork in the surrounding community ${ }^{16}$ HAP established a women's section in the fall of 1974 and hired Lin Farley, who taught a course on women and work. A journalist who had worked as an associated press reporter, Farley was a longtime activist in radical feminist politics and was a member of the Furies collective, a radical lesbian organization in Washington DC. She testified at the 1971 New York Radical Feminist Conference on Rape and later moved to New York City and joined the radical group Lesbian Feminist Liberation. ${ }^{17}$

Farley recruited two friends to work with her at HAP, Susan Meyer and Karen Sauvigné, who joined HAP in January 1975. Meyer grew up near New York City and attended college at the University of Michigan, graduating in 1968. She was an antiwar activist in college, where she worked with Students for a Democratic Society, and later participated in Quaker training on community organizing and nonviolent community dispute resolution with Sauvigné. When she moved back to New York City, Meyer continued to participate in leftist political activity. She taught English as a second language and did some organizing in the Latino/a community in Brooklyn. Meyer also participated in consciousness-raising groups, came out as a lesbian, and became active in radical feminist politics. Meyer was part of the Rat collective in New York, an underground radical feminist newspaper, and worked with Lesbian Feminist Liberation as head of the media committee. Meyer met Farley in the early 1970s while Farley was active in the Furies collective, and they later worked together at Lesbian Feminist Liberation. ${ }^{18}$

Sauvigné also grew up near New York City. She graduated from Montclair College in 1970 and then entered Rutgers' graduate program in history. Like Meyer, Sauvigné had been an antiwar activist as a student. In the early 1970s Sauvigné participated in consciousness-raising groups and became active in radical feminist politics, joining New York Radical Feminists. She worked on the issues of rape and marriage and became familiar with the analysis of the role of 
sexual violence in women's oppression. Sauvigné worked at the American Civil Liberties Union (ACLU), including at the Women's Rights Project while Ruth Bader Ginsburg was there, and for the Law Students Civil Rights Research Council (LSCRRC), gaining a legal background, fundraising experience, and contacts that she would later find very useful in organizing against sexual harassment. Meyer and Sauvigné met during the summer of 1974 while Lesbian Feminist Liberation and New York Radical Feminists were doing collaborative political organizing to try to create women's visibility at the annual gay pride march in New York City. Through their activism in the early 1970s, Meyer and Sauvigné learned about feminist theory on rape and domestic violence, which they later used when articulating the issue of sexual harassment. At the HAP, Meyer and Sauvigné shared the job of Research Director, assisting students with research on community organizing. ${ }^{19}$

When Carmita Wood sought help from HAP, Farley, Meyer, and Sauvigné immediately offered their support. The issue of sexual coercion on the job had come up in Farley's class on women and work in the fall of 1974. Because of a scarcity of analytical literature on women and work, Farley had turned to consciousness raising: women in the class talked about their experiences as women on the job. It soon became apparent to Farley that "each one of us had already quit or been fired from a job at least once because we had been made too uncomfortable by the behavior of men." ${ }^{20}$ According to Sauvigné, "Lin's students had been talking in her seminar about the unwanted sexual advances they'd encountered on their summer jobs. And then Carmita Wood comes in and tells Lin her story. We realized that to a person, every one of us $<\mathrm{m}>$ the women on staff, Carmita, the students $<\mathrm{m}>$ had had an experience like this at some point, you know? And none of us had ever told anyone before. It was one of those click, aha! moments, a profound revelation." 21 Sauvigné explained, "We began talking to all the women we 
knew and pretty much everyone could recount a story of how they quit or lost a job sometime in their life because of failing to go along with unwanted sexual advances. It was beginning to seem to us that it was an incredibly widespread phenomena." ${ }^{22}$ While she was in graduate school, Sauvigné herself had been fired from a job as a cocktail waitress when she refused her bosses' sexual advances, and Meyer was sexually harassed while working as an office manager in New York City. ${ }^{23}$

The women quickly recognized that sexual harassment was an important issue to develop in the feminist movement, and they attacked the problem legally and politically. ${ }^{24}$ First, they located attorneys for Wood. Sauvigné contacted Karen DeCrow, the past president of the National Organization for Women who lived in nearby Syracuse and whom Sauvigné knew from her work with the ACLU and LSCRRC. DeCrow located two feminist attorneys to represent Wood on appeal $<\mathrm{m}>$ Maurie Heins and Susan Horn from Syracuse. ${ }^{25}$ While Wood's case did not involve Title VII, the women at HAP immediately realized the potential of Title VII for combating sexual harassment. In a letter to Heins dated 28 March 1975, Sauvigné argued that Title VII should protect women from sex-based intimidation on the job. ${ }^{26}$ On the $5^{\text {th }}$ of April 1975, a news article in the Ithaca Journal quoted Farley making the same point. ${ }^{27}$ Sauvigné attempted to find other people working on the issue. Using mailing lists from the ACLU and LSCRRC, Sauvigné sent a letter to female lawyers asking them if they had any cases involving sexual harassment, and she surveyed women's organizations about the issue. She did not receive many responses, but she did receive one from Catharine MacKinnon, whom Sauvigné already knew because MacKinnon had been a LSCRRC intern too. Sauvigné had met MacKinnon in 1974 when Sauvigné and Meyer were visiting Farley in Ithaca and MacKinnon passed through town as a traveling folk singer. ${ }^{28}$ 
In addition to organizing legal support for Wood, the women at HAP sought to generate political support by forming a workingwomen's organization, which they called Working Women United, and planning a speakout “in order to break the silence.” According to Sauvigné, the speakout was a "mechanism for public consciousness raising," with which she was familiar from her work with New York Radical Feminists. ${ }^{29}$ In her letter to Heins, Sauvigné explained, “we hope to politicize the issue and begin to ease up women's self-consciousness about speaking about it. I think that sexual abuse on the job is an issue very much akin to rape and we will need to do a lot of consciousness-raising to free women up to talk about it." ${ }^{30}$ Quoted in a press release issued by HAP, Farley said: "When women came forward to tell their stories about rape and abortion it culminated in changes in the New York State rape laws and in a landmark Supreme Court decision. It took women telling the untold truth about our lives to show how wide spread and damaging these problems really are to activate these changes. Sexual exploitation of working women needs the same exposure. That's the purpose of the Speakout." ${ }^{31}$ Farley explicitly tied her earlier activism to the speakout on sexual exploitation of workingwomen.

In planning for the speakout, Meyer suggested that they agree upon one term to use in the publicity. Several phrases had been used in the weeks since Wood had approached HAP, including "sexual abuse," "sexual coercion," "sexual intimidation," and "sexual harassment." Farley, Sauvigné, Meyer, and several other women agreed to sit down and decide upon one term to use. They wanted a term that included not only blatant examples of sexual abuse but also more subtle behaviors. The women met at the HAP offices and made a collective decision to use the term "sexual harassment" because it conveyed the broad array of conduct they intended to include. ${ }^{32}$ Sauvigné described the meeting as follows: "Eight of us were sitting in an office of Human Affairs brainstorming about what we were going to write on posters for our speakout. 
We were referring to it as 'sexual intimidation,' 'sexual coercion,' 'sexual exploitation on the job.' None of those names seemed quite right. We wanted something that embraced a whole range of subtle and unsubtle persistent behaviors. Somebody came up with 'harassment.' Sexual harassment! Instantly we agreed. That's what it was." 33 The earliest written use of the term “sexual harassment” in the Working Women's Institute archives appears in the 28 March 1975 letter from Sauvigné to Heins. The term was used publicly in a press release, dated 3 April 1975, issued by the HAP, and soon thereafter it began appearing in press coverage of the issue. ${ }^{34}$

A broad cross section of workingwomen in Tompkins County, New York, attended a meeting on the $2^{\text {nd }}$ of April 1975, launching a campaign "to expose the problem of sexual exploitation of women on the job." ${ }^{35}$ At this meeting several women spoke of their experiences of sexual harassment, including Wood and twenty-three-year-old Janet Oestreich, who told of her experiences of sexual harassment by customers when she was a waitress. On the $3^{\text {rd }}$ of April 1975, HAP issued a press release about the meeting, quoting Oestreich saying, "I feel very strongly that this subjugation of working women to the power of men who have economic control over them must be stopped!” The press release was picked up in numerous local newspapers, including the Ithaca Journal, the Ithaca New Times, and the Cornell Daily Sun. The press coverage quoted Farley, Meyer, and Wood. ${ }^{36}$

WWU promoted the issue beyond Ithaca as well. On the $21^{\text {st }}$ of April Farley traveled to New York City to testify about sexual harassment before the New York City Human Rights Commission, chaired by Eleanor Holmes Norton, who would later play a key role in shaping federal policy on sexual harassment. Norton was conducting hearings on patterns of discrimination faced by women in blue-collar and service-industry jobs. ${ }^{37}$ According to Farley, Norton "treated the issue with dignity and great seriousness." ${ }^{38}$ In response to Farley's 
testimony, the commission drafted a standard clause for affirmative action agreements addressing "unfair abuse of sexual privacy." ${ }^{\prime 39}$ Enid Nemy, a reporter covering the hearings for the New York Times, heard Farley's testimony and convinced her editor to send her to Ithaca to research the issue of sexual harassment, which she did that summer. ${ }^{40}$

The speakout was a resounding success with over 275 women attending, 20 of whom offered heartfelt testimony about sexual harassment they had experienced. While the press was not allowed at the speakout, the sponsors held a press conference about it the next day. The speakout was covered on all the local radio and television stations and in all the local newspapers. ${ }^{41}$ After the speakout, 40 women met and officially launched Working Women United. ${ }^{42} \mathrm{WWU}$ members hoped to encourage collective action, including unionization, and aspired to be like 9-to-5, a grassroots organization of female office workers that formed in 1973 in Boston to combat sex discrimination in employment. ${ }^{43}$ Their first newsletter, called Labor Pains, appeared in August 1975. The activities of WWU led to the first national press coverage of sexual harassment, also in August 1975, when the New York Times published a story by Nemy. ${ }^{44}$ The article was syndicated nationally, appearing in over a dozen newspapers around the country, including the Philadelphia Bulletin and the Chicago Tribune..$^{45}$ According to Sauvigné, "Nemy's story put sexual harassment on the map." ${ }^{46}$ The story, despite appearing in the Family/Style section of the Times, provided a serious, well-researched, and thorough treatment of the issue of sexual harassment. Nemy's article was followed several months later by a Wall Street Journal article on sexual harassment in January 1976, which also discussed the speakout. ${ }^{47}$ This article was longer than the New York Times article and more business oriented, but, similar to the Times' article, treated the issue with great seriousness. In the same month that the Wall Street Journal article appeared, Redbook magazine published a questionnaire on sexual 
harassment in the workplace, which provoked a groundswell of response from readers about their experiences of sexual harassment. ${ }^{48}$ In addition to appearing in print media, the issue received television coverage. In February and March 1976, CBS in New York broadcast a series of news programs on sexual harassment at work. ${ }^{49}$

WWU members realized the need to do research and public education on the issue of sexual harassment, so in August 1975 they created a separate organization, the Working Women United Institute (WWUI), which was incorporated as a 501(c)(3) nonprofit organization with the goal "to engage in research, education and litigation on issues of concern to working women."50 Meyer was the Executive Director and Sauvigné was the Program Director. According to Sauvigné, they modeled themselves after the ACLU by creating a nonprofit organization focused on research and public education separate from the membership organization that could engage in political activities. Sauvigné's contacts at the ACLU helped WWUI to become established, including consulting on organizational development and tax-exempt status, as well as providing office space and equipment for part of one summer. ${ }^{51}$ By 1977, WWU had become inactive in part because of tension between transient Cornell students and local working-class women, but also because Farley had withdrawn due to disagreements with other members, and Meyer and Sauvigné had turned their energies to the success of the WWUI.

In June 1977, in search of a better place to run a national organization, conduct research, and obtain funding, Meyer and Sauvigné moved WWUI to New York City. At this time they decided to focus exclusively on sexual harassment. ${ }^{52}$ They established an office in the basement of Central Presbyterian Church at Park Avenue and 64th Street, which they found through Church Women United, and operated on a shoestring budget. ${ }^{53}$ Grant money came slowly at first. The Institute applied for funding from the Ms. Foundation, which at first denied their 
request on the grounds that they believed it did not address a "bread and butter issue," but the foundation later gave the Institute its first grant for $\$ 3,000 .{ }^{54}$ Both Sauvigné and Meyer volunteered their time and had other jobs; Sauvigné worked part-time at the College for Human Services, and Meyer drove a cab. ${ }^{55}$ In its first few years, WWUI worked to raise awareness of sexual harassment through the media and public speaking, provided information and referrals to targets of sexual harassment, built a resource library and a legal brief bank, conducted research on sexual harassment, and supported public policy initiatives. ${ }^{56}$ Meyer and Sauvigné also sought to get other women's organizations to work on the issue. At first they experienced resistance because these organizations had so many important issues they were addressing, but Meyer and Sauvigné were soon able to convince others that sexual harassment should be a priority issue. ${ }^{57}$

Just as WWU began with the 4 May 1975 speakout in Ithaca, the Working Women United Institute's rebirth in New York City was marked by an October 1977 speakout cosponsored with $M s$. magazine. About two hundred women attended the four-hour speakout held on Saturday, the $22^{\text {nd }}$ of October at the Community Church of New York on the lower east side. Speakers included Gloria Steinem, Meyer and Sauvigné, Jill Goodman of the ACLU Women's Rights Project, Robin Morgan, and Karen Lindsey, a writer for $M s .{ }^{58}$ Ten women presented prepared testimony, including sexual harassment plaintiff Adrienne Tomkins, Freada Klein, and Farley, then many more women spoke during an "open mike" period. Unlike the first speakout, the organizers allowed journalists, but they excluded male journalists during the "open mike" period. The speakout received television and newspaper coverage, including a New York Times article mentioning WWUI and quoting Meyer and Sauvigné. ${ }^{59}$ In November, Ms. magazine did a cover story on sexual harassment, and then many other magazines and newspapers ran stories on sexual harassment. ${ }^{60}$ Meyer and Sauvigné began to appear regularly 
on television and radio shows, including "Good Morning America," the "Phil Donahue Show," and the "Mike Douglas Show." ${ }^{\prime 61}$ For this groundbreaking work, Meyer and Sauvigné received the Mademoiselle Award in $1977 .{ }^{62}$ They also had many speaking engagementsand conducted workshops on sexual harassment for harassed women, private corporations, foundations, unions, the government, and voluntary organizations. ${ }^{63}$ They established a speaker's bureau and collected information on sexual harassment. ${ }^{64}$ Later they would testify before Congress about sexual harassment, provide input to the Equal Employment Opportunity Commission as they developed sexual harassment guidelines, and provide litigation support and referrals for attorneys and plaintiffs. WWUI grew significantly in the late 1970s and early 1980s, funded by several large grants from the New York Foundation, Exxon, and the Ford Foundation, and a large number of medium-sized grants, several from church organizations. With this support, the Institute sought to "alter popular consciousness about sexual harassment" through their activities. ${ }^{65}$

\section{Alliance Against Sexual Coercion}

Another significant organization formed in the mid-1970s to address sexual harassment was the Alliance Against Sexual Coercion, founded in Cambridge in June 1976 by Freada Klein, Lynn Wehrli, and Elizabeth Cohn-Stuntz. These three women first encountered the issue of sexual harassment while working at the Washington DC Rape Crisis Center ${ }^{66}$ All had extensive experience working on the issue of rape. Klein graduated from University of California at Berkeley in 1974 with a bachelor's degree in criminology. While at Berkeley, Klein worked with the Bay Area Women Against Rape, one of the first rape crisis centers in the United States. In the summer of 1974 she moved to Washington DC to do political work with a national focus and 
to start graduate work in women's studies at George Washington University. While in DC, she worked with the Washington DC Rape Crisis Center and was a founding member of the Feminist Alliance Against Rape, a national network of rape crisis centers which published a bimonthly newsletter. She also worked with Prisoners Against Rape in Lorton, Virginia, a self-help and education group for male prisoners who had raped and been raped. Because of her involvement with this group, Klein was invited by Cambridge Documentary Films to participate in making a documentary about rape called "Rape Culture," which interviewed convicted rapists at the Lorton prison. As a result, Klein began traveling on a regular basis to Cambridge and also collaborated with the Our Bodies, Ourselves collective on the rape chapter in a mid-1970s edition. ${ }^{67}$ Klein eventually moved to Cambridge.

Wehrli and Cohn-Stuntz also worked on the issue of rape before founding AASC. In addition to volunteering at the DC Rape Crisis Center, Wehrli worked with the Feminist Alliance Against Rape and taught a course on rape and U.S. institutions at the Women's School. Later Wehrli moved to Boston to enter the Massachusetts Institute of Technology's master's program in urban planning. Cohn-Stuntz, who graduated from Smith College, had written her senior thesis on the emotional reactions of women to rape. She became a psychiatric social worker in DC and volunteered at the Rape Crisis Center. Cohn-Stuntz moved to Cambridge because her husband was going to Harvard Business School. ${ }^{68}$ The backgrounds of these three women in rape crisis work, and the radical feminist theory and networks they encountered through this work, strongly influenced their theoretical and practical orientation toward the issue of sexual harassment.

While at the Rape Crisis Center, Klein and others on the hotline shift received phone calls from women experiencing severe sexual coercion on the job. Klein quickly realized the unique legal and emotional problems of women sexually assaulted by their bosses and co-workers and 
saw that neither rape crisis centers nor workingwomen's organizations provided services that addressed the needs of these women. Klein contacted Cohn-Stuntz and Wehrli, and they established the Alliance Against Sexual Coercion as a collective. In order to avoid having to put their energies into applying for grant money to pay their salaries, the members earned their livelihoods elsewhere but put their major energies and commitment into AASC. ${ }^{69}$ The goal of AASC was to eliminate workplace sexual harassment. ${ }^{70}$ Several Boston-area organizations supported AASC, including 9-to-5, the Cambridge Rape Crisis Center, and Transition House, a battered women's shelter. ${ }^{71}$

From its inception in June 1976, AASC provided crisis-intervention counseling, but in the first year members focused mostly on intensive research into understanding sexual harassment and developing ways to deal with it. ${ }^{72}$ In August 1976, AASC surveyed over two hundred rape crisis centers and workingwomen's groups about employment-related sexual assault. Every group that responded had received these types of calls, but few of them had information on the issue and none of them had programs to deal with it. ${ }^{73}$ AASC originally focused on developing a sexual harassment protocol for rape crisis centers with the hope that the centers would take on this issue, an approach they later abandoned when it became clear that rape and workplace sexual harassment were very different issues because of the ongoing nature of workplace sexual harassment and its relationship of workplace sexual harassment to women's economic well-being. ${ }^{74}$

In late 1976 AASC published its first position paper, written by Klein and Wehrli. ${ }^{75}$ That same year Wehrli completed one of the earliest in-depth theoretical studies of sexual harassment in the form of a master's thesis at MIT entitled "Sexual Harassment at the Workplace: A Feminist Analysis and Strategy for Social Change." Written with the help of Klein and other 
AASC members, Wehrli's thesis documented AASC's early theoretical analysis of sexual harassment. Wehrli pursued the theme of male power by developing what she called a "dominance" theory of sexual harassment. She argued that sexual harassment in the workplace was both an expression of and a means of perpetuating the unequal power relationships between men and women and between employers and employees. ${ }^{76}$

In December 1976, AASC organized a strategy meeting of women from local feminist organizations to come together and share their ideas on how to deal with the issue most effectively. AASC also spread the word by helping to organize and participating in the first Take Back the Night march in Boston in 1977. ${ }^{77}$ The responses of women's organizations were mixed. Many believed that sexual harassment was not as important as other issues they were addressing so they did not prioritize it. ${ }^{78}$

After this first year, AASC decided to be more service oriented rather than research oriented because they felt it was "more vital to touch women's lives, not just write about the issue." ${ }^{, 79}$ In June 1977, AASC began providing a broad range of services to victims of sexual harassment, including emotional support, legal information and referrals, unemployment eligibility information, vocational and educational counseling referrals, and rap groups. ${ }^{80}$ AASC operated a telephone hotline for sexually harassed women, choosing to make contact with women workers independently through the hotline rather than by working through unions or other workplace organizations because only 11 percent of women workers were unionized at the time and unions were not initially interested in addressing sexual harassment. ${ }^{81}$ AASC focused on workplace sexual harassment but was also concerned about harassment in other contexts, and later became very involved with sexual harassment in education. ${ }^{82}$ In addition to offering help to individuals, AASC assisted women's groups in other communities to develop similar services 
and conducted educational programs, seminars, and workshops on sexual harassment. ${ }^{83}$ AASC sought to "serve as a clearinghouse for cases and additional information involving" sexual harassment. ${ }^{84}$ Klein described AASC's goal in the November 1977 Ms. cover story on sexual harassment: "I hope this becomes a large movement like rape, like battered women because it's also an issue of violence against women. To have services, resources, and options available in every community throughout the country would be the greatest thing that could happen." 85

The $M s$. cover story had a similar effect on AASC as it had had on WWUI. The magazine included an article on the work of AASC with contact information. ${ }^{86}$ This coverage led to an explosion of calls to AASC from sexually harassed women and from the press, as it had for WWUI. ${ }^{87}$ Many other magazines and newspapers then discussed the work of AASC. ${ }^{88}$ By 1979 , AASC was self-supporting from fees collected from literature, speaking, and training. ${ }^{89}$

Despite their decision not to become a research-focused organization, AASC members published prolifically on sexual harassment, including both resource materials and theoretical analyses. Many of the publications of AASC members placed sexual harassment within a broader critique of capitalism, patriarchy, and racism. AASC's first informational brochure alternated between practical advice for sexually harassed women and a far-reaching critique of United States culture and capitalist economic system. AASC argued that sexual harassment was a form of violence against women that reflected and reinforced women's subordinate status in society. Described as a "highly effective tool of social control," violence against women resulted from “our country's history of relying upon violence as a method of problem solving” and from the fact that "men are socialized to dominate women through the use and threat of violent behavior." 90 They argued that men sexually harass women whom they see as threats to their masculinity, power, or economic status. Furthermore, both the unequal status of workers and 
employers as well as the unequal status of men and women reinforced each other in cases of sexual harassment. They argued, "Sexist attitudes, along with racist and classist beliefs, are vital parts of the U.S. economic system. Not until an egalitarian and democratic work structure is established will sexual harassment be eradicated."91 They described women's economic vulnerability in the labor force, their long history of sexual harassment in the United States, and the psychological effects of sexual harassment.

Other publications by AASC members also placed sexual harassment within a broader critique of capitalism, patriarchy, and racism. For example, AASC members Martha Hooven and Nancy McDonald, who worked at the DC Rape Crisis Center, argued in a 1978 article in Aegis that capitalism contributed to the proliferation of sexual harassment because the conditions of work under capitalism made women vulnerable to sexual harassment. They argued, "capitalism feeds on sexism and racism. $" 92$ They suggested that ending sexual harassment might require abolishing capitalism. Hooven and Klein coauthored an article entitled "Is Sexual Harassment Legal?" which was deeply pessimistic about the ability of government and the legal system to treat women and people of color fairly. They explained that AASC did not seek to pass new laws against sexual harassment because they believed that the legal system oppressed women and was racist and classist. They argued, "it is doubtful that enforcement of [a new law] will differ greatly from usual enforcement practices $<$ m $>$ i.e., a married middle class white woman, if harassed by a man with less societal status, will probably receive benefits; while a poor, Third World or lesbian woman, particularly if harassed by a 'respectable' man, may find compensation under this new law difficult to obtain." ${ }^{93}$ Also, they noted that legal remedies only addressed harassment after the fact and they sought to prevent harassment before it occurred. Instead, they sought to use existing laws and provide public education and support services for victims of sexual 
harassment. According to Hooven and Klein, the primary benefit of a new law would be as a form of public education, rather than for its deterrent effect: "more women will be encouraged to speak out about their victimization and the chances for finding workplace support are increased." $" 94$

Similar to the WWUI, AASC made pioneering efforts to help women experiencing sexual harassment and to convince people that sexual harassment was a serious issue that required attention. Their informational brochures, myth and fact sheets, and other informational resources began the process of raising public awareness of sexual harassment. Through its publications, AASC made an important and powerful contribution to the feminist analysis of sexual harassment. Locating the roots of sexual harassment not only in sexism, but also in classism and racism, AASC members produced a broad-based critique of society that incorporated insights from both radical and socialist feminisms. They also developed a broad range of strategies to address the problem, calling not only for legal redress, but also for collective organizing and direct action.

\section{Conclusion}

Feminist activism in the mid-1970s created physical and intellectual spaces for women to speak out about sexual coercion on the job. As feminists before had done with abortion, rape, and domestic violence, naming the violation and speaking out about it legitimized their feelings of violation. Naming "sexual harassment" framed the issue in a way that made the conduct visible, enabling women to speak out and share their outrage and their pain, and to declare the conduct a violation. Feminists then engaged in an extensive publicity campaign to get the word out, reach women, and educate the public. The issue resonated powerfully with workingwomen 
across the country, especially working-class women, many of whom were women of color, who relied on their income for survival. Feminist activism influenced the development of laws against sexual harassment. In particular, attorneys representing the early sexual harassment plaintiffs on appeal used feminist studies, surveys, and theory to argue their cases, and media attention generated by the work of feminist organizations would help convince judges of the seriousness of the issue. Feminists' groundbreaking efforts against sexual harassment spurred a broad-based and diverse movement that by the end of the 1970s would proliferate around the country and would challenge traditional sex role expectations and male-control of the workplace.

This movement grew out of the broader women's movement, which provided an organizational base, communication networks, strategies, and ideology for the founders of the movement against sexual harassment. Activists from Working Women United and the Alliance Against Sexual Coercion used the existing networks of feminist organizations and rape crisis centers to collect and disseminate information about sexual harassment. They also used many of the strategies of the women's movement, holding speakouts, exposing the myths about sexual harassment in "myth/fact sheets," using the courts, and demanding legal and institutional reforms. In terms of ideology, sexual harassment activists borrowed upon a central principle of the anti-rape movement that rape was not about sex but about violence when they argued that sexual harassment was not about sex but about power and economic abuse, and amounted to employment discrimination. An early AASC publication described the contributions of the rape crisis movement and workingwomen's organizations to resistance against sexual harassment: "Rape crisis centers redefined rape as an act of violence, refuted myths about women's sexuality, and pointed to aspects of women's socialization which keep women silent victims. Workingwomen's organizations revealed women's low pay and low labor force status, and the 
numbers of women and families dependent on women's income." ${ }^{95}$ Drawing upon multiple strands of the second wave women's movement both ideologies and networks the early activists against sexual harassment identified, named, and theorized a common violation that many women experienced as status quo in the workplace. Joining ideas and strategies of liberal, radical, and socialist feminisms, activists sought to challenge the broader systems of inequality in the workplace, hoping to transform America into a democratic and egalitarian nation.

This close look at the grassroots of sexual harassment activism in the mid-1970s reveals some valuable lessons about the second wave of the women's movement. First, this work calls into question the usefulness of an oversimplified division between types of feminisms when analyzing grassroots activism. The founders of both WWU and AASC drew upon multiple sources from within the women's movement. Karen Sauvigné, for example, had experience with radical theory and action in New York Radical Feminists but was also knowledgeable about using legal reform for social change from her experience at the ACLU. She brought all of this experience to bear on her work on sexual harassment with Working Women United. Sauvigné, Lin Farley, and Susan Meyer had backgrounds in lesbian feminist politics, including the Rat collective, the Furies collective, and Lesbian Feminist Liberation. Freada Klein, Lynn Wehrli, and Elizabeth Cohn-Stuntz had worked in the anti-rape movement, with DC Rape Crisis Center, and the Feminist Alliance Against Rape in Washington DC. We also see in early activism against sexual harassment the integration of socialist feminist perspectives and analysis in the publications of the AASC. The women who initiated the movement against sexual harassment had a range of experience in social protest movements and created a network of activists that spanned a range of ideologies and issues, all of which contributed to the shape of the emerging movement against sexual harassment. 
Second, this article, along with my 2004 Feminist Studies article on race, class, and sexual harassment, calls into question the idea that the second wave was just a white middleclass women's movement. As the work of women's studies scholar Maria Bevacqua on rape, historian Premilla Nadasen on welfare rights, historian Dennis Deslippe on working-class feminisms, and women's studies scholar Kimberly Springer and sociologist Benita Roth on African American and Chicana feminisms reveal, the second wave of the women's movement was diverse, and there were a number of issues that drew diverse women into collaborative activism. ${ }^{96}$ Sexual harassment was an important issue to women because it affected so many, so often, across race and class lines and was rooted in fundamental concerns about economic survival and personal integrity. The fight against sexual harassment brought women together across differences to fight a common problem. By the late 1970s women in unions and nontraditional occupations such as construction and mining became a dominant presence in the movement against sexual harassment. ${ }^{97}$

This article is part of a broader turn among scholars toward drawing a much more complex and diverse picture of the women's movement in the late-twentieth-century United States. ${ }^{98}$ Rather than focusing on the stars of the movement, this literature is emphasizing the importance of grassroots activism to the movement and illuminating the ways that women found common cause across difference to create feminist change. With all due respect to such influential and important leaders as Catharine MacKinnon, this article offers a glimpse into some of the committed activists who built the movement against sexual harassment. Moreover, this literature also challenges the declension narrative of the second wave; much of the diverse grassroots activism, including that against sexual harassment, was just beginning in the mid1970s. ${ }^{99}$ The movement against sexual harassment succeeded in many ways, not just in changing 
laws but also in raising awareness and creating institutional and organizational frameworks for dealing with it. Most employers and schools have policies against sexual harassment; governments keep statistics on it; studies of it continue to be conducted by governments, academics, and activists; and lawsuits continue to be filed. Rates of sexual harassment are still high and challenges remain, but gender relations in the U.S. workplace have been fundamentally transformed over the last thirty years by a movement initiated in the 1970s by grassroots feminist activists.

\section{NOTES}

${ }^{1}$ Karen Lindsey, "Sexual Harassment on the Job and How To Stop It," Ms., November 1977, 47. ${ }^{2}$ Speakout on Sexual Harassment of Women at Work, 4 May 1975, Ithaca, NY, (transcript), p. 1, Karen Sauvigné Papers, Brooklyn, NY, Private Collection, hereafter Sauvigné Papers.

${ }^{3}$ Karen Sauvigné, in discussion with the author, Brooklyn, NY, 4 February 2001.

${ }^{4}$ Susan Brownmiller, In Our Time: Memoir of a Revolution (New York: The Dial Press, 1999), 282; see also Lin Farley, Sexual Shakedown: The Sexual Harassment of Women on the Job (New York: McGraw-Hill Book Company, 1978), xii.

${ }^{5}$ Speakout on Sexual Harassment of Women at Work, 4 May 1975, Ithaca, NY, (transcript), p. 31, Sauvigné Papers.

${ }^{6}$ Corne v. Bausch \& Lomb, 390 F. Supp. 161 (D. Ariz., 1975); Barnes v. Train, 13 Fed. Empl.

Prac. Cas. 123 (D.D.C. 1974); Miller v. Bank of America, 418 F. Supp. 233 (N.D. Cal., 1976);

Tomkins v. Public Service Electric and Gas, 422 F. Supp. 553 (D.N.J. 1976).

${ }^{7}$ EEOC v. Rogers, 454 F.2d 234 ( $2^{\text {nd }}$ Cir. 1971) cert. denied, 406 U.S. 957 (1972). 
${ }^{8}$ Williams v. Saxbe, 413 F. Supp. 654 (D.D.C. 1976), rev'd in part and vacated in part, 190 F.2d 343 (D.C. Cir. 1978); Barnes v. Train, 13 Fed. Empl. Prac. Cas. 123 (D.D.C. 1974), rev'd sub nom, Barnes v. Costle, 561 F. 2d 983 (D.C. Cir. 1977); Meritor Savings Bank v. Vinson, 477 U.S. 57, 67 (1986); Alexander v. Yale University, 631 F.2d 178 ( ${ }^{\text {nd }}$ Cir. 1980); Continental Can Company v. Minnesota, 297 N.W.2d 241, 246 (Minn. 1980); and Bundy v. Jackson, 641 F. 2d 934, 944 (D.C. Cir. 1981). For an elaboration of this history, see Carrie N. Baker, "Race, Class, and Sexual Harassment in the 1970s," Feminist Studies 30, no. 1 (2004): 7-27.

${ }^{9}$ Sara M. Evans, Tidal Wave: How Women Changed America at Century's End (New York: Free Press, 2003), 25-26; Ruth Rosen, The World Split Open: How the Modern Women's Movement Changed America (New York: Penguin Books, 2000), 74-75; and Myra Marx Ferree and Beth B. Hess, Controversy and Coalition: The New Feminist Movement (Boston: G. K. Hall \& Company, 1985), 55.

${ }^{10}$ Dorothy Sue Cobble, The Other Women's Movement: Workplace Justice and Social Rights in Modern America (Princeton: Princeton University Press, 2004), 209-11; Drew Whitelegg, "Cabin Pressure: The Dialectics of Emotional Labour in the Airline Industry," The Journal of Transport History 23, no. 1 (2002): 73-86; and "Fly Me," Time Magazine, 15 November 1971.

${ }^{11}$ Susan M. Hartmann, The Other Feminists: Activists in the Liberal Establishment (New Haven, CT: Yale University Press, 1998).

${ }^{12}$ Quotation from John Stoltenberg, "Male-on-Male Sexual Harassment," Feminista 1, no. 7 (1997), http://www.feminista.com/archives/v1n7/stoltenberg.html. See also Fred Strebeigh, "Defining Law on the Feminist Frontier," New York Times Magazine, 6 October 1991, 53; Sheila Tobias, Faces of Feminism: An Activist's Reflections on the Women's Movement (Boulder, CO: Westview Press, 1997), 114-15; Jeffrey Toobin, “The Trouble with Sex: Why the Law of Sexual 
Harassment Has Never Worked,” The New Yorker, 9 February 1998, 49; Sara Leitch,

“Conference Will Debate Future of Sex Harassment Law,” Yale Daily News, 27 February 1998, http://www.yaledailynews.com/article.asp?AID=9852; Rosen, The World Split Open, 187; and Estelle B. Freedman, No Turning Back: The History of Feminism and the Future of Women (New York: Ballantine Books, 2002), 290.

${ }^{13}$ Frances Olsen, “The Outsider: Catharine MacKinnon,” The American Lawyer, 6 December 1999, C04.

${ }^{14}$ Catharine Mackinnon, Sexual Harassment of Working Women (New Haven, CT: Yale University Press, 1979); and Meritor Savings Bank v. Vinson, 477 U.S. 57 (1986).

${ }^{15}$ Nancy MacLean, Freedom Is Not Enough: The Opening of the American Workplace (Cambridge, MA: Harvard University Press, 2006), 265-99; Kimberly Springer, Living for the Revolution: Black Feminist Organizations, $1968<n>1980$ (Durham, NC: Duke University Press, 2005); Benita Roth, Separate Roads to Feminism: Black, Chicana, and White Feminist Movements in America's Second Wave (New York: Cambridge University Press, 2004); Anne Enke, "Smuggling Sex Through the Gates: Race, Sexuality, and the Politics of Space in Second Wave Feminism,” American Quarterly 55, no. 4 (2003): 634-67; Stephanie Gilmore, “The Dynamics of the Second-Wave Feminist Activism in Memphis, $1971<\mathrm{n}>1982$ : Rethinking the Liberal/Radical Divide,” NWSA Journal 15, no. 1 (2003): 94-117; Premilla Nadasen, "Expanding the Boundaries of the Women's Movement: Black Feminism and the Struggle for Welfare Rights," Feminist Studies 28, no. 2 (2002): 271-301; Judith Ezekiel, Feminism in the Heartland (Columbus: Ohio State University Press, 2002); Anne M. Valk, “'Mother Power”: The Movement for Welfare Rights in Washington, D.C., 1966<n>1972," Journal of Women's 
History 11, no. 4 (2000): 34-58; and Nancy Naples, Grassroots Warriors: Activist Mothering, Community Work, and the War on Poverty (New York: Routledge, 1998), 131-53.

${ }^{16}$ Brownmiller, In Our Time, 279.

${ }^{17}$ Susan Meyer, in discussion with the author, New York, NY, 17 February 2001; and Brownmiller, In Our Time, 279-80.

${ }^{18}$ Meyer, discussion; Brownmiller, In Our Time, 279-80; and Lawrence Stessin, “Two Against Harassment," New York Times, 23 December 1979, sec. 3, 7.

${ }^{19}$ Sauvigné, discussion; Meyer, discussion; Brownmiller, In Our Time, 279-80; and Stessin, “Two Against Harassment," 7. Meyer and Sauvigné were lesbian partners. Their relationship ended in 1982. Sauvigné does not believe that her sexual identity was significant to her activism on the issue of sexual harassment and that it did not play much of a role in her recognition of sexual harassment as a form of exploitation.

${ }^{20}$ Farley, Sexual Shakedown, 11-12.

${ }^{21}$ Sauvigné, interview with Brownmiller, quoted in Brownmiller, In Our Time, 281.

${ }^{22}$ Sauvigné, discussion.

${ }^{23}$ Ibid.; and Meyer, discussion.

${ }^{24}$ Karen Sauvigné to “Mauri”[Maurie Heins], 28 March 1975, Working Women’s Institute Archives, Barnard Center for Research on Women, New York, NY, hereafter WWIA.

${ }^{25}$ Sauvigné, discussion.

${ }^{26}$ Sauvigné to "Mauri," 28 March 1975, WWIA.

${ }^{27}$ Barbara Geehan, “Women Fight 'Intimidation,'” Ithaca Journal, 5 April 1975, 4.

${ }^{28}$ Sauvigné, discussion; and Brownmiller, In Our Time, 281.

${ }^{29}$ Brownmiller, In Our Time, 281. 
${ }^{30}$ Sauvigné to "Mauri," 28 March 1975, WWIA.

${ }^{31}$ Lin Farley, quoted in Cornell University Human Affairs Program, "Working Women Join To

Fight Sexual Exploitation,” 3 April 1975 (press release), WWIA.

${ }^{32}$ Sauvigné, discussion; and Meyer, discussion.

${ }^{33}$ Sauvigné, interview with Brownmiller, quoted in Brownmiller, In Our Time, 281.

${ }^{34}$ Cornell University Human Affairs Program, "Working Women Join To Fight Sexual

Exploitation," 3 April 1975 (press release), WWIA; and Brenda Jacobs, "Working Women Form

Campaign to Expose Sexual Harassment,” Cornell Daily Sun, 18 April 1975, 15.

${ }^{35}$ Cornell University Human Affairs Program, “Working Women Join To Fight Sexual

Exploitation,” 3 April 1975 (press release), WWIA.

${ }^{36}$ Geehan, "Women Fight 'Intimidation,", 4; L. Scott, "Protest Sexploitation," Ithaca New Times, 13 April 1975; and Jacobs, "Working Women Form Campaign to Expose Sexual Harassment," 15.

${ }^{37}$ Lin Farley, "Special Disadvantages of Women in Male-Dominated Work Setting,"

Testimony Before the Commission on Human Rights of the City of New York, Hearings on Women in Blue-Collar, Service, and Clerical Occupations, 21 April 1975, WWIA; Barbara Geehan, "Ithacan Testifies on Job Sexual Harassment," Ithaca Journal, 22 April 1975, 6; and “Women’s Organized Labor Pains,” New York Post, 22 April 1975.

${ }^{38}$ Farley, interview with Brownmiller, quoted in Brownmiller, In Our Time, 283.

${ }^{39}$ Enid Nemy, "Women Begin to Speak Out Against Sexual Harassment at Work," New York Times, 19 August 1975, 38.

${ }^{40}$ Brownmiller, In Our Time, 283.

${ }^{41}$ Sauvigné, discussion. 
${ }^{42}$ Julie Friedman, “Speak Out Draws Tears and Anger," Labor Pains 1, no. 1 (1975): 1.

${ }^{43}$ Sauvigné, discussion.

${ }^{44}$ Nemy, "Women Begin to Speak Out Against Sexual Harassment at Work," 38.

45،'Sexual Harassment: Now a National Issue,” Labor Pains 1, no. 1 (1975): 7.

${ }^{46}$ Sauvigné, interview with Brownmiller, quoted in Brownmiller, In Our Time, 284.

${ }^{47}$ Mary Bralove, “A Cold Shoulder, Career Women Decry Sexual Harassment by Bosses and Clients," Wall Street Journal, 19 January 1976, 1.

48““A Redbook Questionnaire: How Do You Handle Sex on the Job?” Redbook, January 1976, 74-

75.

${ }^{49}$ Meyer, discussion.

${ }^{50}$ Working Women United Institute, "Project Description and Request for Funds: Research on Sexual Harassment on the Job," 1975, WWIA; and Sauvigné, discussion.

${ }^{51}$ Sauvigné, discussion.

${ }^{52}$ Ibid.; Constance Backhouse and Leah Cohen, The Secret Oppression: Sexual Harassment of Working Women (Toronto: Macmillan of Canada, 1978), 156; and K. C. Wagner, “A Socialist Feminist Perspective," in Not for Women Only: Social Work Practice for a Feminist Future, ed. Mary Bricker-Jenkins and Nancy R. Hooyman (Silver Spring, MD: National Association of Social Workers, 1986), 65.

${ }^{53}$ The office was located in the subbasement of the church, "underlooking Park Avenue," according to Sauvigné. Many people donated time and supplies to set up the office. Sauvigné, discussion; and Meyer, discussion. 
${ }^{54}$ Sauvigné, discussion; and Meyer, discussion.The National Women's Employment Project was another example of a group that discouraged working on sexual harassment during this early period. Ezekiel, Feminism in the Heartland, 211-12.

${ }^{55}$ Sauvigné, discussion.

${ }^{56}$ Karen Lindsey, “A National Resource,” Ms., November 1977, 49.

${ }^{57}$ Meyer, discussion.

${ }^{58}$ New York Women Speakout About Sexual Harassment on the Job, 22 October 1977 (flyer), WWIA.

${ }^{59}$ Danielle Crittenden, "Women Tell of Sexual Harassment at Work," New York Times, 25

October 1977, 35; and Letter Protesting Comments of Stanley Siegel on WABC-TV, Dated 27 October 1977, WWIA. Meyer and Sauvigné appeared on the David Hartmann morning news show in New York. Meyer, discussion.

${ }^{60}$ Lindsey, "Sexual Harassment on the Job and How To Stop It," 47. The cover of the magazine had a picture of dolls, not people, because, as Sauvigné said, "they couldn't think of a way that they could have real people posed and not have it look lewd, so they didn't.” Sauvigné, discussion. For coverage in other magazines, see, for example, Women's Action Alliance, "N.Y. Speakout: Women Describe Indignities They Face at Work,” Women's Agenda, December 1977, 9; "Sex on the Job: Where We Are Now," Redbook, April 1978, 38; Merrill Rogers Skrocki, “Sexual Pressure on the Job,” McCall's, March 1978, 43; L. C. Pogrebin, "Sex Harassment: The Working Woman,” Ladies Home Journal, June 1977, 24; Janet Harris, “Dealing With Bosses,” Family Circle, 24 April 1978, 191; Susan Hobart, “Awareness Helps Women Overcome Sexual Indignities,” The Oregonian, 23 January 1978, sec. B, 1; Dorothy Austin, “Institute Fights Sex Harassment," Milwaukee Sentinel, 2 June 1978, 10; Patsy Miller, "Fighting Harassment a Job," 
Fort Worth Star-Telegram, 7 June 1978; and Jane White, “Sexual Harassment: New Groups Fighting Problem," Pueblo Star-Journal and Sunday Chieftain, 20 August 1978. According to Sauvigné, they never had a problem getting press coverage because sexual harassment had "sex" in its name. Sauvigné, discussion.

${ }^{61}$ Working Women's Institute, 1979 Annual Program Report and Audited Financial Statement, p. 1, Sauvigné Papers; "Sexual Harassment on the Job,” Phil Donahue Show (Princeton, NJ: Films for the Humanities and Sciences, 1988) (1977 Phil Donahue show with Susan Meyer and Karen Sauvigné); and Meyer, discussion.

62“"Mlle Awards: 13 Success Stories,” Mademoiselle, November 1977.

${ }^{63}$ Karen Sauvigné to Karin Lippert of Ms. Magazine, 17 August 1978, WWIA; Backhouse and Cohen, The Secret Oppression, 157; Somerset County National Organization for Women, Flyer Advertising Speakout on Sexual Harassment on the Job, Somerville, NJ, 17 November 1977, Sauvigné Papers; and Susan Meyer and Karen Sauvigné, “Sexual Harassment on the Job: Legal Remedies" (paper presented at Employment Discrimination Panel Discussion, New York State International Women's Year Meeting, 9 July 1977), Sauvigné Papers.

${ }^{64}$ Backhouse and Cohen, The Secret Oppression, 154-57.

${ }^{65}$ Sauvigné to Lippert, 17 August 1978, WWIA.

${ }^{66}$ Backhouse and Cohen, The Secret Oppression, 157; Alliance Against Sexual Coercion, Sexual Harassment at the Workplace (Cambridge, MA: Alliance Against Sexual Coercion, 1977), 23; and Connie Backhouse et al., Fighting Sexual Harassment: An Advocacy Handbook (Boston: Alyson Publications, Inc. and The Alliance Against Sexual Coercion, 1981), 7.

${ }^{67}$ Freada Klein, in discussion with the author, 26 March 2001, San Francisco, CA. 
${ }^{68}$ Freada Klein to "Dear Sisters," 7 August 1976, Alliance Against Sexual Coercion Ephemeral Materials, 1976<n>77, Wilcox Collection of Contemporary Political Movements, Schlesinger Library, Radcliffe College, Cambridge, MA; and Klein, discussion, 26 March 2001.

${ }^{69}$ Backhouse and Cohen, The Secret Oppression, 158 . At one point, Klein ran a family violence program that was a demonstration project funded by the Department of Justice's Law Enforcement Assistance Administration. Klein, discussion, 26 March 2001.

${ }^{70}$ Backhouse et al., Fighting Sexual Harassment, 7.

${ }^{71}$ Rochelle Lefkowitz, "Help for the Sexually Harassed: A Grass-Roots Model,” Ms., November 1977, 49. The first office of AASC was at 575 Massachusetts Avenue in Cambridge, but they later moved to 120 Boylston Street on the Boston Commons. Freada Klein, in discussion with the author, 25 June 2001, New York, NY.

${ }^{72}$ Backhouse and Cohen, The Secret Oppression, 158.

${ }^{73}$ Freada Klein and Lynn Wehrli, "Sexual Coercion on the Job?" Sister Courage, October 1976, 6; "Interview with the Alliance Against Sexual Coercion," Sister Courage, June 1977, 2; Kathy Shank, "Sexual Harassment in the Classroom," Sister Courage, May 1978, 8; Jane Albert, "Tyranny of Sex in the Office," Equal Times, 7 August 1977, 7; and Klein, discussion, 26 March 2001. According to Klein, the protocol of rape crisis centers was advocacy with the police, the hospital, the district attorney and the court, none of which was relevant in the employment context.

${ }^{74}$ Klein, discussion, 26 March 2001.

${ }^{75}$ Klein and Wehrli, "Sexual Coercion on the Job?" 6; and "Working Women Unite!" Feminist Alliance Against Rape Newsletter, September<n>October 1976, 7. 
${ }^{76}$ Lynn Wehrli, "Sexual Harassment at the Workplace: A Feminist Analysis and Strategy for Social Change" (master's thesis, Massachusetts Institute of Technology, 1976), 55-79.

77، Interview with the Alliance Against Sexual Coercion," Sister Courage, June 1977, 2.

${ }^{78}$ Freada Klein, in discussion with the author, 4 April 2001, San Francisco, CA.

79،"Interview with the Alliance Against Sexual Coercion,” 2.

${ }^{80}$ Backhouse et al., Fighting Sexual Harassment, 7; and Lefkowitz, "Help for the Sexually Harassed," 49.

${ }^{81}$ Alliance Against Sexual Coercion, “Organizing Against Sexual Harassment,” 26, 29.

${ }^{82}$ Albert, "Tyranny of Sex in the Office," 7; and Alliance Against Sexual Coercion, University

Grievance Procedures, Title IX and Sexual Harassment on Campus (Cambridge, MA: Alliance Against Sexual Coercion, 1980).

${ }^{83}$ Lefkowitz, "Help for the Sexually Harassed," 49.

${ }^{84}$ Form Letter for Informational Packet from Alliance Against Sexual Coercion Ephemeral Materials, 1976<n>77, Wilcox Collection of Contemporary Political Movements, Schlesinger Library, Radcliffe College, Cambridge, MA.

${ }^{85}$ Lindsey, "Sexual Harassment on the Job and How to Stop It," 78.

${ }^{86}$ Lefkowitz, "Help for the Sexually Harassed," 49. Freada Klein and some other AASC members attended the October 1977 speakout in New York City. Klein, discussion, 26 March 2001.

${ }^{87}$ Backhouse, et al., Fighting Sexual Harassment, 80.

${ }^{88}$ Adrienne Munich, “Seduction in Academe,” Psychology Today, February 1978, 82.

${ }^{89}$ Klein, discussion, 26 March 2001.

${ }^{90}$ Alliance Against Sexual Coercion, Sexual Harassment, 4-5.

${ }^{91}$ Ibid., 11. 
${ }^{92}$ Martha Hooven and Nancy McDonald, "The Role of Capitalism: Understanding Sexual Harassment," Aegis, November<n>December 1978, 31-33.

${ }^{93}$ Martha Hooven and Freada Klein, “Is Sexual Harassment Legal?” Aegis, 1978, ${ }^{94}$ Ibid.

${ }^{95}$ Alliance Against Sexual Coercion, Sexual Harassment, 23-24.

${ }^{96}$ Maria Bevacqua, “Anti-Rape Coalitions: Radical, Liberal, Black, and White Feminists Challenging Boundaries," in Forcing Radical Alliances Across Difference: Coalition Politics for the New Millennium, ed. Jill Bystydzienski and Steven P. Schacht (New York: Rowman \& Littlefield, 2001), 163-76; Nadasen, "Expanding the Boundaries of the Women's Movement"; Dennis A. Deslippe, "Rights, Not Roses": Unions and the Rise of Working-Class Feminism, $1945<n>1980$ (Urbana: University of Illinois Press, 2000); Springer, Living for the Revolution; and Roth, Separate Roads to Feminism.and See also Rosalyn Baxandall and Linda Gordon, eds., Dear Sisters: Dispatches from the Women's Liberation Movement (New York: Basic Books, 2000).

${ }^{97}$ For more discussion on these different parts of the movement against sexual harassment, see my other articles "Race, Class, and Sexual Harassment in the 1970s," and "Blue-Collar Feminists and the Link Between Sexual Harassment and Male Domination," in In the Company of Men: Male Dominance and Sexual Harassment, ed. Jim Gruber and Phoebe Morgan (Boston: Northeastern University Press, 2004), 243-70.

${ }^{98}$ Cynthia Harrison, “Creating a National Feminist Agenda: The Women’s Action Alliance and Feminist Coalition Building in the 1970s," in Feminist Coalitions: Historical Perspectives on Second-Wave Feminism in the United States, ed. Stephanie Gilmore (Urbana: University of Illinois Press, 2007); Springer, Living for the Revolution; Wendy Kline, "'Please Include This in 
Your Book': Readers Respond to Our Bodies, Ourselves," Bulletin of the History of Medicine 79, no. 1 (2005): 81-110; Roth, Separate Roads to Feminism; Enke, "Smuggling Sex Through the Gates"; Gilmore, "The Dynamics of the Second-Wave Feminist Activism in Memphis"; Nadasen, "Expanding the Boundaries of the Women's Movement"; Ezekiel, Feminism in the Heartland; Kathy Davis, "Feminist Body/Politics as World Traveller: Translating Our Bodies, Ourselves," The European Journal of Women's Studies 9, no. 3 (2002): 223-47; Bevacqua, “AntiRape Coalitions”; Valk, “"Mother Power”; Naples, Grassroots Warriors; and Amy Farrell, “'Like a Tarantula on a Banana Boat': Ms. Magazine, 1972<n>1989," in Feminist Organizations: Harvest of the New Women's Movement, ed. Myra Marx Ferree and Patricia Yancey Martin (Philadelphia: Temple University Press, 1995), 53-68.

${ }^{99}$ Sara M. Evans, "Beyond Declension: Feminist Radicalism in the 1970s and 1980s," in The World the 60s Made: Politics and Culture in Recent America, ed. Van Gosse and Richard Moser (Philadelphia: Temple University Press, 2003), 52-66; and Sara M. Evans, "Re-Viewing the Second Wave," Feminist Studies 28, no. 2 (2002): 264. 